\title{
Effects of plant growth regulators on growth and carbohydrate accumulation in shoots and roots of two almond rootstock seedlings
}

Mostafa MoBLI, Bahram BANINASAB*

Dep. Hortic., Coll. Agric., Isfahan Univ. Technol., Isfahan 84156-83111, Iran bbanin@cc.iut.ac.ir

* Correspondence and reprints

Received 12 March 2008 Accepted 20 May 2008

Fruits, 2008, vol. 63, p. 363-370 (C) 2008 Cirad/EDP Sciences All rights reserved DOI: $10.1051 /$ fruits:2008032 www.fruits-journal.org RESUMEN ESPAÑOL, p. 370
Effects of plant growth regulators on growth and carbohydrate accumulation in shoots and roots of two almond rootstock seedlings.

Abstract - Introduction. Prunus amygdalus and P. webbii can be used as rootstocks for almond cultivars due to their adaptability to severe environmental conditions. However, the time required for seedlings to reach a suitable size for transplanting may take 1 to 3 years. Our study tested the effects of foliar application of growth regulators on the vegetative growth and carbohydrate accumulation in shoots and roots of these species. Materials and methods. Six-week-old seedlings were treated with gibberellic acid $\left(\mathrm{GA}_{3}\right)\left(100 \mathrm{mg} \cdot \mathrm{L}^{-1}\right)$ alone or with $\mathrm{GA}_{3}$ followed by ethephon $[(100$ and 200) $\left.\mathrm{mg} \cdot \mathrm{L}^{-1}\right]$, or chlormequat chloride (CCC) $\left[(500\right.$ and 1000$\left.) \mathrm{mg} \cdot \mathrm{L}^{-1}\right]$, or paclobutrazol (PBZ) $[(500$ and 1000) $\left.\mathrm{mg} \cdot \mathrm{L}^{-1}\right]$. Results and discussion. Most levels of plant growth regulators significantly enhanced seedling growth. However, $\mathrm{GA}_{3}$ alone was most effective on stem height, leaf area, and shoot fresh and dry weights of both almond species. The thickest stems of $P$. amygdalus and $P$. webbii were obtained from the application of $100 \mathrm{mg} \mathrm{GA} \cdot \mathrm{L}^{-1}$ followed by application of $(1000$ and 500) $\mathrm{mg} \mathrm{PBZ} \cdot \mathrm{L}^{-1}$, respectively. In both species, PBZ significantly increased leaf chlorophyll content compared with the controls as well as with the other treatments. Application of $\mathrm{GA}_{3}$ alone on P. webbii and of $\mathrm{GA}_{3}$ followed by $100 \mathrm{mg}$ ethephon $\mathrm{L}^{-1}$ on $P$. amygdalus showed the highest root number, and root fresh and dry weights. High levels of soluble sugars and starch in the shoots and roots of both species were observed when $\mathrm{GA}_{3}$ application was followed by PBZ. Conclusion. These results demonstrated that application of plant growth regulators to the seedlings might be a useful way of enhancing growth of $P$. amygdalus and $P$. webbii and reducing the time and cost of seedling production.

Iran Islamic Republic / Prunus amygdalus / Prunus webbii / rootstocks / seedlings / growth / plant growth substances / gibberellic acid / ethephon / chlormequat / paclobutrazol

Effets des régulateurs de croissance végétaux sur la croissance et l'accumulation d'hydrate de carbone dans les tiges et racines de deux porte-greffes d'amandier.

Résumé - Introduction. Prunus amygdalus et $P$. webbii peuvent être utilisés comme porte-greffes de cultivars d'amandier du fait de leur adaptabilité à de sévères conditions environnementales. Cependant, le temps requis pour que les plantes atteignent une taille apte à la transplantation peut être de 1 à 3 ans. Notre étude a analysé les effets de l'application foliaire de régulateurs de croissance sur la croissance végétative et l'accumulation d'hydrate de carbone dans les tiges et les racines de cette espèce. Matériel et méthodes. Des plants de 6 semaines ont été traités avec de l'acide gibbérélique $\left(\mathrm{GA}_{3}\right)\left(100 \mathrm{mg} \cdot \mathrm{L}^{-1}\right)$ seul ou avec $\mathrm{GA}_{3}$ suivi de l'application d'éthéphon [(100 et 200$) \mathrm{mg} \cdot \mathrm{L}^{-1}$ ], ou de chlorure de chlorocholine (CCC) $\left[\left(500\right.\right.$ et 1000) $\left.\mathrm{mg}^{-1} \mathrm{~L}^{-1}\right]$, ou de paclobutrazol (PBZ) [(500 et 1000) $\left.\mathrm{mg} \cdot \mathrm{L}^{-1}\right]$. Résultats et discussion. La plupart des doses de régulateurs de croissance ont augmenté de manière significative la croissance des plantes. Cependant, $\mathrm{GA}_{3}$ utilisé seul a été le plus efficace pour augmenter la hauteur des tiges, la surface foliaire et les poids frais et secs des tiges des deux espèces d'amandier étudiées. Les tiges les plus épaisses de $P$. amygdalus et de $P$. webbii ont été obtenues à partir de l'application de $100 \mathrm{mg} \mathrm{GA3} \cdot \mathrm{L}^{-1}$ suivie de l'application de (1000 et 500) $\mathrm{mg} \mathrm{PBZ} \cdot \mathrm{L}^{-1}$, respectivement. Pour les deux espèces, l'application de PBZ a augmenté de manière significative la teneur en chlorophylle des feuilles comparée à celle des plantes témoin et à celle des plantes des autres traitements. L'application de $\mathrm{GA}_{3}$ seul sur $P$. webbii et de $\mathrm{GA}_{3}$ suivi de $100 \mathrm{mg}$ éthéphon $\mathrm{L}^{-1}$ sur $P$. amygdalus a donné le nombre de racines le plus élevé, ainsi que les poids frais et secs de racines les plus importants. On a observé des niveaux élevés de sucres et d'amidon solubles dans les tiges et les racines des deux espèces quand l'application de $\mathrm{GA}_{3}$ a été suivie de celle de PBZ. Conclusion. Ces résultats ont démontré que l'application de régulateurs de croissance végétaux pourrait être efficace pour augmenter la croissance de $P$. amygdalus et de $P$. webbii et réduire la période et le coût de production de ces porte-greffes.

Iran République islamique / Prunus amygdalus / Prunus webbii / porte greffe / plantule / croissance / substance de croissance végétale / acide gibbérellique / éthéphon / chlorméquat / paclobutrazol 


\section{Introduction}

Iran is an important center for wild and domesticated almond trees. Bitter almond (Prunus amygdalus var. amara) seedlings are the primary rootstock for almond in Iran. However, $P$. webbii, a wild almond species used in semi-desert areas to control soil erosion, is also used as an almond rootstock due to its adaptability to severe environmental conditions $[1,2]$. It takes 1 to 3 years for a seedling of bitter or wild almond to reach the suitable size for budding. Therefore, increasing the growth rate can shorten this time.

Plant growth regulators are widely used for modifying plant growth and development in many plants [3]. Paclobutrazol (PBZ) [(2RS, 3RS)-1-(4-chlorophenyl)-4,4dimethyl-2-(1,2,4-triazol-1-yl) pentan-3-ol], a member of the triazole plant growth inhibitor group, is a broad-spectrum gibberellin biosynthesis inhibitor [4]. The primary action of PBZ is to inhibit ent-kaurene oxidase, which catalyzes the sequential oxidations from ent-kaurene to ent-kaurenoic acid in the early sequence of gibberellin biosynthesis [5], resulting in reduced plant height $[6,7]$, increased chlorophyll content [8], and enhanced carbohydrate accumulation in shoots and roots [9, 10].

Chlormequate chloride (CCC) [(2-chloroethyl) trimethyl ammonium chloride], a gibberellin biosynthesis inhibitor, has been used on cereals since the mid-1960s [11] CCC is a favorable choice for general application since it is easily broken down in the environment [12]. Chlormequate chloride disrupts gibberellin biosynthesis prior to the steps at which PBZ acts, inhibiting cyclization of geranylgeranyl diphosphate to copalyl diphosphate [4]. Aphalo et al. [13] found that application of CCC to containerized silver birch seedlings partially inhibited their height, growth and dry mass accumulation without negative effects on root growth in the following spring. They concluded that CCC could be a useful tool in nursery management. Studies also demonstrated that CCC reduced tree vigor and stem length and increased shoot diameter [14, 15]

Ethephon, which decomposes into gaseous ethylene, chloride and phosphate ions, is known to cause changes in vascular anatomy [16]. Research has found that ethephon increased xylem wall thickness [17, 18], inhibited cell elongation and promoted lateral expansion [19]. Neel reported that application of ethylene gas to the lower halves of young tree trunks enclosed in plexiglass tubes causes extreme thickening of the trunk [20].

The objective of our study was to study the effects of ethephon, CCC and PBZ applied after gibberellic acid $\left(\mathrm{GA}_{3}\right)$ treatment on growth, rooting and allocation of assimilates of two almond rootstock seedlings.

\section{Materials and methods}

Viable dehulled nuts of $P$. amygdalus var. amara and sound nuts of $P$. webbii were selected using a flotation technique [21]. The sound nuts were scarified mechanically and then soaked in tap water for $48 \mathrm{~h}$. The nuts were mixed with moist peat moss $[3$ peat moss: 1 seed $(\mathrm{V} / \mathrm{V})]$ and stratified by keeping them at $(5 \pm 1){ }^{\circ} \mathrm{C}$ for $30 \mathrm{~d}$. After stratification, nuts were sown directly in $5-\mathrm{kg}$ black plastic bags filled with a 1:1:1 (V/V/V) mixture of sand, leaf mold and loam soil in early spring. The plastic bags were then kept in an outdoor nursery area and irrigation was done. The experiment was arranged in a completely randomized design with eight treatments, four replications and four plants per replication (plastic bag).

Six-week-old seedlings were sprayed with $100 \mathrm{mg} \cdot \mathrm{L}^{-1} \mathrm{GA}_{3}$. The control plants were treated with distilled water. Four weeks after $\mathrm{GA}_{3}$ treatment, seedlings were then sprayed with (100 or 200) mg ethephon $\cdot \mathrm{L}^{-1}$ or $(500$ or 1000$) \mathrm{mg} C C C \cdot \mathrm{L}^{-1}$ or $(500$ or 1000) mg PBZ $\mathrm{L}^{-1}$. Twelve weeks later, plants were removed from the containers. The media were carefully washed from the roots. The length and diameter of stems, leaf size, chlorophyll content, fresh and dry weight of shoots, root number, root diameter, and fresh and dry weight of roots were determined. Leaf chlorophyll content was measured photometrically in $80 \%$ acetone [22]. Leaf size and root number and diameter were measured using the Delta-T SCAN 
image analysis system (Windias software). Shoot and root samples were lyophilized, ground and stored at $-20^{\circ} \mathrm{C}$ until sugar analysis. Soluble sugars were extracted with $80 \%$ ethyl alcohol, and starch was extracted with perchloric acid. The extracted soluble sugars and starch were quantified with anthrone using a spectrophotometer at $630 \mathrm{~nm}$ [23].

All data were subjected to analysis of variance (ANOVA) and means were compared using the least significant difference (LSD) test at $P<0.05$, using MSTATC (Michigan State Univ., MI, USA) software.

\section{Results and discussion}

\subsection{Effect of $\mathrm{GA}_{3}$, ethephon, $\mathrm{CCC}$ and PBZ on seedling height}

Twelve weeks after the application of $\mathrm{GA}_{3}$ and its combination with other chemicals, seedling height of both $P$. amygdalus and $P$. webbii was increased compared with control (table I). Nevertheless, this increase was not statistically significant for $\mathrm{GA}_{3}+$ $200 \mathrm{mg}$ ethephon $\mathrm{L}^{-1}$ or $\mathrm{GA}_{3}+1000 \mathrm{mg}$ $\mathrm{PBZ} \cdot \mathrm{L}^{-1}$ in $P$. amygdalus (table I). The tallest seedlings of $P$. amygdalus and $P$. webbii were obtained from the application of $\mathrm{GA}_{3}$ alone. However, application of ethephon, CCC or PBZ following $\mathrm{GA}_{3}$ reduced the increasing effect of $\mathrm{GA}_{3}$ on plant height (table I). This result indicates an inhibitory effect of ethephon, CCC and PBZ on plant height. The effect of $\mathrm{GA}_{3}$ on stem elongation was consistent with previous findings with pecan [24] and wild species of pistachio [25].

\subsection{Effect of $\mathrm{GA}_{3}$, ethephon, $\mathrm{CCC}$ and PBZ on stem diameter}

Stem diameter was also increased by $\mathrm{GA}_{3}$ alone in both species (table I). In P. amygdalus, application of ethephon, CCC and PBZ following $\mathrm{GA}_{3}$ showed a further increase in stem diameter, with the most effect caused by $1000 \mathrm{mg} \mathrm{PBZ} \cdot \mathrm{L}^{-1}$ (154\% of control). In $P$. webbii, application of CCC and PBZ following $\mathrm{GA}_{3}$ also showed a fur- ther increase in stem diameter, with the thickest stem $(2.36 \mathrm{~mm})$ caused by $500 \mathrm{mg}$ $\mathrm{PBZ} \cdot \mathrm{L}^{-1}$ (table I). Rahemi and Baninasab [25] reported similar findings with $\mathrm{GA}_{3}$ in two wild species of pistachio. They concluded that $\mathrm{GA}_{3}$ significantly increased stem diameter of some selected P. mutica and $P$. khinjuk seedlings. The increasing effect of PBZ on stem diameter is in agreement with that reported by Costa et al. [26] in pear. It has been reported that CCC increased shoot diameter of mango [14]. Ethephon also increased seedling diameter only in $P$. amygdalus compared with $\mathrm{GA}_{3}$ alone (table I). Neel [20] reported that ethylene increased eucalyptus seedling trunk diameters. He demonstrated ethylene thickened Eucalyptus fasiculosa stems by stimulating phloem development. Experiments have demonstrated a potential role of ethylene in secondary growth in stem tissues [16, 18]. Application of ethrel has been shown to stimulate cambial cell division in both gymnosperm and angiosperm trees [16, 18]. Gurusinghe and Shackel [16] reported similar findings with almond trees. They concluded that ethephon induced biochemical and anatomical changes that could increase the amount of cell wall material in the sheared area of the cambial zone.

\subsection{Effect of $\mathrm{GA}_{3}$, ethephon, $\mathrm{CCC}$ and PBZ on leaf size, chlorophyll content and shoot mass}

Application of $\mathrm{GA}_{3}$ alone significantly increased leaf size in both $P$. amygdalus and P. webbii (table I), confirming the results reported by Marcelle and Oben [27]. However, application of $\mathrm{GA}_{3}$ followed by (100 or 200) mg ethephon $\mathrm{L}^{-1}$ or $1000 \mathrm{mg}$ $\mathrm{PBZ} \cdot \mathrm{L}^{-1}$ reduced leaf size in $P$. webbii.

The leaf chlorophyll content was significantly increased when (500 or 1000) mg $\mathrm{PBZ} \cdot \mathrm{L}^{-1}$ were applied after $\mathrm{GA}_{3}$ application in both species compared with the other treatments (table I). Previous studies have shown that chlorophyll content was affected by PBZ treatment $[8,28]$. The increase in chlorophyll content in seedling leaves treated with PBZ may be attributed to the increase in endogenous cytokinin content. 


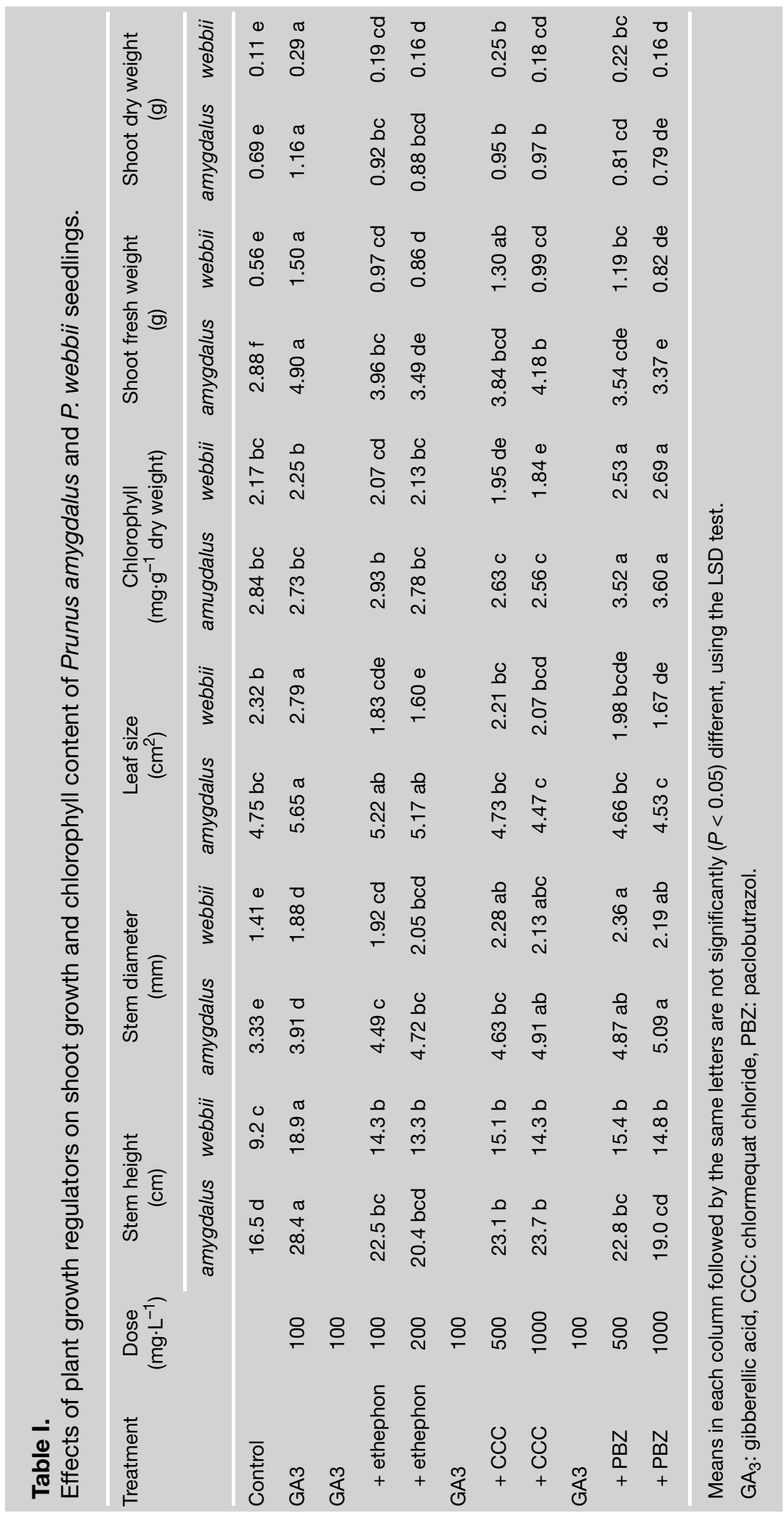


Table II.

Effects of plant growth regulators on root growth of Prunus amygdalus and $P$. webbii seedlings.

\begin{tabular}{|c|c|c|c|c|c|c|c|c|c|}
\hline \multirow[t]{2}{*}{ Treatment } & \multirow[t]{2}{*}{$\begin{array}{l}\text { Dose } \\
\left(\mathrm{mg} \cdot \mathrm{L}^{-1}\right)\end{array}$} & \multicolumn{2}{|c|}{ Root number } & \multicolumn{2}{|c|}{$\begin{array}{l}\text { Root diameter } \\
\qquad(\mathrm{mm})\end{array}$} & \multicolumn{2}{|c|}{$\begin{array}{l}\text { Root fresh weight } \\
\text { (g) }\end{array}$} & \multicolumn{2}{|c|}{$\begin{array}{l}\text { Root dry weight } \\
\text { (g) }\end{array}$} \\
\hline & & amygdalus & webbii & amygdalus & webbii & amygdalus & webbii & amygdalus & webbii \\
\hline Control & & $33132.7 \mathrm{c}$ & $6257.6 \mathrm{~cd}$ & $1.21 \mathrm{~d}$ & $1.48 \mathrm{~d}$ & $4.16 \mathrm{de}$ & $0.64 \mathrm{~b}$ & $0.60 \mathrm{~cd}$ & $0.06 \mathrm{~b}$ \\
\hline GA3 & 100 & 37475.5 bc & $10881.0 \mathrm{a}$ & $1.68 \mathrm{ab}$ & $2.06 \mathrm{a}$ & $4.40 \mathrm{cde}$ & $0.94 a$ & $0.59 \mathrm{~cd}$ & $0.10 \mathrm{a}$ \\
\hline GA3 & 100 & & & & & & & & \\
\hline + ethephon & 100 & $50572.2 \mathrm{a}$ & 7013.4 bcd & $1.19 \mathrm{~d}$ & $1.57 \mathrm{~cd}$ & $8.62 \mathrm{a}$ & $0.75 \mathrm{ab}$ & $1.19 \mathrm{a}$ & $0.07 \mathrm{~b}$ \\
\hline + ethephon & 200 & $41146.5 \mathrm{bc}$ & $8462.5 \mathrm{bc}$ & $1.07 \mathrm{~d}$ & $1.68 \mathrm{bcd}$ & $5.35 c$ & $0.83 a b$ & $0.71 \mathrm{c}$ & $0.08 a b$ \\
\hline GA3 & 100 & & & & & & & & \\
\hline$+\mathrm{CCC}$ & 500 & 39964.0 bc & $8775.9 \mathrm{ab}$ & $1.28 \mathrm{~cd}$ & $1.82 \mathrm{abc}$ & $4.98 \mathrm{~cd}$ & $0.84 a b$ & $0.70 \mathrm{c}$ & $0.08 a b$ \\
\hline$+\mathrm{CCC}$ & 1000 & $43621.3 \mathrm{ab}$ & 8507.2 bc & $1.33 \mathrm{bcd}$ & $1.63 \mathrm{bcd}$ & $7.06 \mathrm{~b}$ & $0.77 \mathrm{ab}$ & $0.95 b$ & $0.08 a b$ \\
\hline GA3 & 100 & & & & & & & & \\
\hline$+\mathrm{PBZ}$ & 500 & $35746.2 \mathrm{bc}$ & $6021.7 \mathrm{~d}$ & $1.63 \mathrm{abc}$ & $1.71 \mathrm{bcd}$ & $4.53 \mathrm{cde}$ & $0.75 a b$ & $0.57 \mathrm{~cd}$ & $0.08 a b$ \\
\hline+ PBZ & 1000 & $33825.0 \mathrm{c}$ & $5773.5 \mathrm{~d}$ & $1.72 \mathrm{a}$ & $1.93 a b$ & $3.45 \mathrm{e}$ & $0.69 \mathrm{~b}$ & $0.48 d$ & $0.07 \mathrm{~b}$ \\
\hline
\end{tabular}

Means in each column followed by the same letters are not significantly $(P<0.05)$ different, using the LSD test.

$\mathrm{GA}_{3}$ : gibberellic acid, CCC: chlormequat chloride, PBZ: paclobutrazol.

It has been proposed that PBZ stimulates cytokinin synthesis that, in turn, enhances chloroplast differentiation and chlorophyll biosynthesis, and prevents chlorophyll degradation [29-31].

Application of most plant growth regulators significantly increased shoot fresh and dry weights in both species compared with control. The largest increase was found when $\mathrm{GA}_{3}$ was applied alone (table I). Addition of the ethephon, CCC and PBZ to $\mathrm{GA}_{3}$ reduced the effect of $\mathrm{GA}_{3}$. A similar result was reported from other research [25, 28].

\subsection{Effect of $\mathrm{GA}_{3}$, ethephon, $\mathrm{CCC}$ and PBZ on root quality}

Root quality is an important index of seedling quality and a critical factor for transplanting. Spraying $P$. amygdalus seedlings with $\mathrm{GA}_{3}$ plus $100 \mathrm{mg}$ ethephon $\mathrm{L}^{-1}$ or $1000 \mathrm{mg}$ CCC $\cdot \mathrm{L}^{-1}$ increased root number as well as root fresh and dry weight compared with control (table II). Spraying P. webbii seedlings with $\mathrm{GA}_{3}$ alone or $\mathrm{GA}_{3}$ plus $500 \mathrm{mg} \mathrm{CCC} \cdot \mathrm{L}^{-1}$ increased root number compared with control, whereas only $\mathrm{GA}_{3}$ alone increased root fresh and dry weight (table II). Studies have shown that $\mathrm{GA}_{3}$ may inhibit or promote root growth in different species [32, 33]. Our results agree with those of Campbell and Pan et al. [34, 35].

In both species, application of $\mathrm{GA}_{3}$ alone or followed by $1000 \mathrm{mg} \mathrm{PBZ} \cdot \mathrm{L}^{-1}$, and also in $P$. amygdalus $\mathrm{GA}_{3}+500 \mathrm{mg} \mathrm{PBZ} \cdot \mathrm{L}^{-1}$ and in P. webbii $\mathrm{GA}_{3}+500 \mathrm{mg} \mathrm{CCC} \cdot \mathrm{L}^{-1}$, significantly increased root diameter compared with control (table II). This is similar to the results of Davis et al. [6], who reported plants treated with PBZ had thicker roots than untreated controls.

\subsection{Effect of $\mathrm{GA}_{3}$, ethephon, $\mathrm{CCC}$ and PBZ on shoot and root soluble sugar and starch content}

Application of PBZ in both species' seedlings, and $\mathrm{GA}_{3}$ plus $100 \mathrm{mg}$ ethephon $\cdot \mathrm{L}^{-1}$ in $P$. amygdalus and $\mathrm{GA}_{3}+500 \mathrm{mg} \mathrm{CCC} \cdot \mathrm{L}^{-1}$ in P. webbii, significantly increased shoot soluble sugars compared with controls (table III). Spraying of both species' seedlings with PBZ also significantly increased root soluble sugars compared with control (table III). Increased soluble sugar content in all plant parts following foliar application of PBZ was 
Table III.

Effects of plant growth regulators on carbohydrate content $\left(\mathrm{mg} \cdot \mathrm{g}^{-1}\right.$ dry weight) of shoots and roots of Prunus amygdalus and $P$. webbii seedlings.

\begin{tabular}{|c|c|c|c|c|c|c|c|c|c|}
\hline \multirow[t]{2}{*}{ Treatment } & \multirow{2}{*}{$\begin{array}{c}\text { Dose } \\
\left(\mathrm{mg} \cdot \mathrm{L}^{-1}\right)\end{array}$} & \multicolumn{2}{|c|}{ Shoot soluble sugars } & \multicolumn{2}{|c|}{ Root soluble sugars } & \multicolumn{2}{|c|}{ Shoot starch } & \multicolumn{2}{|c|}{ Root starch } \\
\hline & & amygdalous & webbii & amygdalous & webbii & amygdalous & webbii & amygdalous & webbii \\
\hline Control & & $97.1 \mathrm{c}$ & $66.4 \mathrm{c}$ & $12.7 \mathrm{bc}$ & $16.2 \mathrm{bcd}$ & $56.6 \mathrm{~d}$ & $23.6 \mathrm{c}$ & $106.7 \mathrm{e}$ & $64.0 \mathrm{f}$ \\
\hline GA3 & 100 & $101.4 \mathrm{bc}$ & $68.8 \mathrm{bc}$ & $10.2 \mathrm{~d}$ & $12.4 \mathrm{~d}$ & $61.2 \mathrm{~cd}$ & $24.0 \mathrm{c}$ & $109.2 \mathrm{e}$ & $60.3 \mathrm{f}$ \\
\hline GA3 & 100 & & & & & & & & \\
\hline + ethephon & 100 & $104.5 a b$ & $70.3 \mathrm{bc}$ & $12.0 \mathrm{~cd}$ & $16.9 \mathrm{abc}$ & $63.2 \mathrm{~cd}$ & $24.8 \mathrm{c}$ & $121.3 \mathrm{~d}$ & $70.2 \mathrm{e}$ \\
\hline + ethephon & 200 & $100.8 \mathrm{bc}$ & $71.6 \mathrm{bc}$ & $13.2 \mathrm{bc}$ & $14.8 \mathrm{~cd}$ & $61.7 \mathrm{~cd}$ & $24.2 \mathrm{c}$ & $128.7 \mathrm{~d}$ & $75.6 \mathrm{e}$ \\
\hline GA3 & 100 & & & & & & & & \\
\hline$+\mathrm{CCC}$ & 500 & $103.4 \mathrm{abc}$ & $74.1 \mathrm{~b}$ & $14.3 \mathrm{~b}$ & $17.4 \mathrm{abc}$ & $69.4 \mathrm{bc}$ & $27.2 \mathrm{bc}$ & $173.2 \mathrm{c}$ & $82.5 d$ \\
\hline$+\mathrm{CCC}$ & 1000 & $100.9 \mathrm{bc}$ & $73.0 \mathrm{bc}$ & $14.6 \mathrm{~b}$ & $18.0 \mathrm{abc}$ & $71.3 \mathrm{~b}$ & 26.8 bc & $168.1 \mathrm{c}$ & $88.6 \mathrm{c}$ \\
\hline GA3 & 100 & & & & & & & & \\
\hline$+\mathrm{PBZ}$ & 500 & $107.1 \mathrm{ab}$ & $81.4 \mathrm{a}$ & $18.1 \mathrm{a}$ & $19.4 a b$ & $82.2 \mathrm{a}$ & $30.5 \mathrm{ab}$ & $202.9 \mathrm{~b}$ & $109.4 \mathrm{~b}$ \\
\hline$+\mathrm{PBZ}$ & 1000 & $109.7 \mathrm{a}$ & $84.2 \mathrm{a}$ & $17.4 \mathrm{a}$ & $20.7 \mathrm{a}$ & $90.4 \mathrm{a}$ & $32.4 \mathrm{a}$ & $227.3 \mathrm{a}$ & $116.1 \mathrm{a}$ \\
\hline
\end{tabular}

Means in each column followed by the same letters are not significantly $(P<0.05)$ different, using the LSD test.

$\mathrm{GA}_{3}$ : gibberellic acid, CCC: chlormequat chloride, PBZ: paclobutrazol.

also found by Mehouachi et al. [9]; however, Yim et al. did not observe any significant effect of PBZ on stem soluble sugar content of rice seedlings [28]. Shoots of $P$. amygdalus treated with $\left(500\right.$ and 1000) $\mathrm{mg} \mathrm{PBZ} \cdot \mathrm{L}^{-1}$ showed a $34 \%$ and $48 \%$ increase in starch content, respectively (table III). The highest shoot starch content in P. webbii was observed with the application of (500 and 1000) $\mathrm{mg} \mathrm{PBZ} \cdot \mathrm{L}^{-1}$ (table III). Mehouachi et al. reported similar findings with citrus rootstock seedlings [9]. In earlier work, apple trees treated with PBZ had increased starch content attributed to a reduced amylase activity [36]. Correlations between stem diameter and shoot soluble sugars $(r=0.73$ and $r=0.76$, respectively, in $P$. amygdalus and $P$. webbii seedlings) and also shoot $\operatorname{starch}(r=0.75$ and $r=0.70$, respectively, in $P$. amygdalus and $P$. webbii seedlings) were identified. These correlations suggest that stem diameter is related to the available amounts of soluble sugars and starch in stem tissues.

Roots, whether treated or not, had higher starch content than shoots (table III). In both P. amygdalus and P. webbii, roots of seed- lings treated with PBZ had markedly higher starch compared with controls and the other treatments (table III). A correlation was also found between stem diameter and root starch $(r=0.78, r=0.72$, respectively, in $P$. amygdalus and $P$. webbii seedlings).

\section{Conclusions}

Our results suggest that spraying of almond seedlings with plant growth regulators might be a useful method of enhancing growth of almond rootstocks to shorten the necessary time for seedlings to reach the transplanting size.

\section{Acknowledgement}

We thank Mrs. M. Ghomsheh and Mr. B. Modarres for their valuable technical assistant throughout this experiment. The authors thank Dr. J. Arvin for the gift of PBZ. This work was supported by the Isfahan University of Technology Research Council, Iran. 


\section{References}

[1] Sabeti H., Forests, trees, and shrubs of Iran, Iran Univ. Sci. Technol. Press, Tehran, Iran, 1994.

[2] Kester D.E., Gradiziel T.M., Almonds, in: Janick J., Moore J.N. (Eds.), Fruit breeding, Vol. III. Nuts, John Wiley and Sons, New York, USA, 1996.

[3] Rademacher W., New types of plant growth retardants: additional perspectives for practical applications in agriculture and horticulture, in: Pharis R.P., Rood S.B. (Eds.), Plant growth substances, Springer Verlag, Berlin, Germany, 1990.

[4] Davis T.D., Curry E.A., Chemical regulation of vegetative growth, Crit. Rev. Plant Sci. 10 (1991) 151-158.

[5] Rademacher W., Bioregulation of crop plants with inhibitions of gibberellin biosynthesis, Proc. Plant Growth Regul. Soc. Am. 24 (1997) 27-31.

[6] Davis T.D., Steffens G.L., Sankhla N., Triazole plant growth regulators, in: Janick J. (Ed.), Hortic. Rev., Timber Press, Oregon, USA, 1988.

[7] Berova M., Zlatev Z., Physiological response and yield of paclobutrazol treated tomato plants (Lycopersicon esculentum Mill.), Plant Growth Regul. 30 (2000) 117-123.

[8] Tekalign T., Hammes P.S., Response of potato grown under non-inductive condition to paclobutrazol: shoot growth, chlorophyll content, net photosynthesis, assimilate partitioning, tuber yield, quality, and dormancy, Plant Growth Regul. 43 (2004) 227-236.

[9] Mehouachi J., Tadeo F.R., Zaragoza S., Primo-Millo E., Talon M., Effects of gibberellic acid and paclobutrazol on growth and carbohydrate accumulation in shoots and roots of citrus rootstock seedlings, J. Hortic. Sci. 71 (1996) 747-754.

[10] Todic S., Tesic D., Beslic Z., The effect of certain exogenous growth regulators on quality of grafted grapevine rooting, Plant Growth Regul. 45 (2005) 121-126.

[11] Herbert C.D., Growth regulation in cerealschance or design, in: McLaren J.S. (Ed.), Chemical manipulation of crop growth and development, Butterworth Sci., London, UK, 1982.

[12] Hampton J.G., Effect of growth retardant soil residues on succeeding agricultural crops, N.Z. J. Exp. Agri. 16 (1988) 167-172.
[13] Aphalo P.S., Rikala R., Sanchez A., Effect of CCC on the morphology and growth potential of containerised silver birch seedling, New For. 14 (1997) 167-177.

[14] Rath S. Das G.C., Effect of ringing and growth retardants on growth and flowering of mango, Acta Hortic. 10 (1979) 101-104.

[15] Marcelle R., Effect of $\mathrm{GA}_{3}$, BA and growth retardant on fruit set in the pear cultivar 'Doyenne Du Comice', Acta Hortic. 149 (1984) 225-229.

[16] Gurusinghe S.H., Shackle K.A., Effect of ethephon (2-chloroethyl phosphonic acid) on vascular cambial strength of almond tree, J. Am. Soc. Hortic. Sci. 120 (1995) 194-198.

[17] Yamaoto F., Angeles G., Kozlowski T.T., Effect of ethereal on stem anatomy of Ulmus Americana seedlings, IAWA Bull. New Ser. 8 (1987) 3-8.

[18] Yamaoto F., Kozlowski T.T., Effect of ethereal on growth and stem anatomy of Pinus halapensis seedlings, IAWA Bull. New Ser. 8 (1987) 11-19.

[19] Arteca R.N., Plant growth substances, principles and application, Chapman and Hall, New York, USA, 1996.

[20] Neel P.L., Growth factors in trunk development of young trees, Tilford P.E, Proc. 45th Int. Shade Tree Conf., Collier Print., Calif., USA, 1969.

[21] Baninasab B., Mobli M., Effects of auxins and application methods on root regeneration of Pistacia mutica seedlings, J. Hortic. Sci. Biotech. 77 (2002) 264-267.

[22] Porra R.J., Thompson W.A., Friedelman P.E., Determination of accurate extraction coefficients and simultaneous equations for assaying chlorophyll $a$ and $b$ extracted with four different solvent: verification of the concentration of chlorophyll standards by atomic absorption spectroscopy, Biochem. Biophys. Acta 975 (1989) 384-394.

[23] McCready R.M., Guggolz J., Silviera V., Owens H.S., Determination of starch and amylose in vegetables, Anal. Chem. 22 (1950) 1156-1159.

[24] Taylor R.M., Influence of gibberellic acid on early patch budding of pecan seedlings, J. Am. Soc. Hortic. Sci. 97 (1972) 667-679.

[25] Rahemi M., Baninasab B., Effect of gibberellic acid on seedling growth in two wild species of pistachio, J. Hortic. Sci. Biotech. 75 (2000) 336-339.

[26] Costa J., Bosch M., Blanco A., Growth and cropping of 'Blanquilla' pear trees treated 
with paclobutrazol, J. Hortic. Sci. 70 (1995) 433-443.

[27] Marcelle R., Oben G., Effects of some growth regulators on $\mathrm{CO}_{2}$ exchange of leaves, Acta Hortic. 34 (1973) 55-60.

[28] Yim K.O., Kwon Y.W., Bayer D.E., Growth responses and allocation of assimilates of rice seedlings by paclobutrazol and gibberellin treatment, J. Plant Growth Regul. 16 (1997) 35-41.

[29] Fletcher R.A., Kallidumbil V., Steele P., An improved bioassay for cytokinin using cucumber cotyledons, Plant Physiol. 69 (1982) 675-677.

[30] Grossman K., Plant growth retardants: their mode of action and benefit for physiological research, in: Karssen C.M., Van Loon L.C., Vreugdehil D. (Eds.), Plant growth regulations, Kulwer Acad. Publ., Neth., 1992.

[31] Banon S., Gonzalez A., Cano E.A., Franco J.A., Fernandez J.A., Growth development and color response of potted Dianthus caryophyllus cv. Mondriaan to paclobutrazol treatment, Sci. Hortic. 94 (2002) 371-377.
[32] Taminoto E., Gibberellin dependent root elongation in Lactuca sativa: recovering from related-suppressed elongation with thickening by low combination of $\mathrm{GA}_{3}$, Plant Cell Physiol. 28 (1987) 963-973.

[33] Kamada H., Ogasawara T., Harada H., Effect of $\mathrm{GA}_{3}$ on growth and tropane alkaloid synthesis in Ri transformed plants of Datura innoxia, in: Takahashi N., Phinney B.O., MacMillan J. (Eds.), Gibberellins, Spriger Verlag, New York, USA, 1991.

[34] Campbell G.M., Effect of ethephon and SADH on quality of clipped and nonclipped tomato transplants, J. Am. Soc. Hortic. Sci. 101 (1976) 648-651.

[35] Pan R., Wang J., Tian X., Influence of ethylene on adventitious root formation in mung bean hypocotyls cutting, Plant Growth Regul. 36 (2002) 135-139.

[36] Steffens G.L., Wang S.Y., Faus, M., Byun C.J., Growth and mineral element status of shoot and spur leaves and fruit of 'Spartan' apple trees treated with paclobutrazol, J. Am. Soc. Hortic. Sci. 110 (1985) 850-855.

\section{Efectos de los reguladores de crecimiento vegetal sobre el crecimiento y la acumulación de hidrato de carbono en los tallos y en las raíces de dos porta injertos de almendro.}

Resumen - Introducción. Prunus amygdalus y P. webbii pueden emplearse como porta injertos de cultivares de almendro gracias a su adaptabilidad a condiciones medioambientales severas. Sin embargo, el tiempo necesario para que las plantas alcancen un tamaño apto para el transplante puede ser de 1 a 3 años. Nuestro estudio analizó los efectos de la aplicación foliar de reguladores de crecimiento sobre el crecimiento vegetativo y la acumulación de hidrato de carbono en los tallos y en las raíces de esta especie. Material y métodos. Se sometieron a tratamiento plantas de 6 semanas con ácido giberélico $\left(\mathrm{GA}_{3}\right)\left(100 \mathrm{mg} \cdot \mathrm{L}^{-1}\right)$ sólo o con $\mathrm{GA}_{3}$ seguido de la aplicación de etefón $\left[\left(100\right.\right.$ y 200) $\left.\mathrm{mg} \cdot \mathrm{L}^{-1}\right]$, o de clormequat (CCC) [(500 y 1000) $\left.\mathrm{mg} \cdot \mathrm{L}^{-1}\right]$, o de paclobutrazol (PBZ) $\left[(500 \mathrm{Y} 1000) \mathrm{mg} \cdot \mathrm{L}^{-1}\right]$. Resultados y discusión. La mayoría de las dosis de reguladores de crecimiento incrementó de modo importante el crecimiento de las plantas. No obstante, $\mathrm{GA}_{3}$ empleado sólo fue el más eficaz para aumentar la altura de los tallos, la superficie foliar así como los pesos en fresco y en seco de los tallos de ambas especies de almendro estudiadas. Los tallos más espesos de $P$. amygdalus y de $P$. webbii se obtuvieron a partir de la aplicación de $100 \mathrm{mg} \mathrm{GA} \cdot \mathrm{L}^{-1}$ seguido de la aplicación de $(1000$ y 500$) \mathrm{mg} \mathrm{PBZ} \cdot \mathrm{L}^{-1}$, respectivamente. Para ambas especies, la aplicación de PBZ incrementó significativamente el contenido de clorofila de las hojas en comparación con aquél de las plantas piloto y con el de las plantas de otros tratamientos. La aplicación de $\mathrm{GA}_{3}$ solo en $P$. webbii y de $\mathrm{GA}_{3}$ seguido de $100 \mathrm{mg}$ etefón $\cdot \mathrm{L}^{-1}$ en $P$. amygdalus dio el número de raíces más elevado, así como los pesos en fresco y en seco de raíces más importante. Se observaron niveles elevados de los azúcares y de almidón solubles en los tallos y en las raíces de ambas especies tras la aplicación de $\mathrm{GA}_{3}$ seguido de la de PBZ. Conclusión. Estos resultados demostraron que la aplicación de reguladores de crecimiento vegetales podrían ser eficaces para aumentar el crecimiento de $P$. amygdalus y de $P$. webbii así como reducir el periodo y el coste de producción de estos porta injertos.

Iran República Islámica / Prunus amygdalus / Prunus webbii / portainjertos / plántulas / crecimiento / sustancias de crecimiento vegetal / ácido giberelico / etefon / chlormequat / paclobutrazol 